\title{
Contrasting impacts of ocean acidification and warming on the molecular responses of $\mathrm{CO}_{2}$-resilient oysters
}

\author{
Priscila Goncalves ${ }^{1,2^{*}}$, Emma L. Thompson ${ }^{1,2,3}$ and David A. Raftos ${ }^{1,2}$
}

\begin{abstract}
Background: This study characterises the molecular processes altered by both elevated $\mathrm{CO}_{2}$ and increasing temperature in oysters. Differences in resilience of marine organisms against the environmental stressors associated with climate change will have significant implications for the sustainability of coastal ecosystems worldwide. Some evidence suggests that climate change resilience can differ between populations within a species. B2 oysters represent a unique genetic resource because of their capacity to better withstand the impacts of elevated $\mathrm{CO}_{2}$ at the physiological level, compared to non-selected oysters from the same species (Saccostrea glomerata). Here, we used proteomic and transcriptomic analysis of gill tissue to evaluate whether the differential response of B2 oysters to elevated $\mathrm{CO}_{2}$ also extends to increased temperature.

Results: Substantial and distinctive effects on protein concentrations and gene expression were evident among B2 oysters responding to elevated $\mathrm{CO}_{2}$ or elevated temperature. The combination of both stressors also altered oyster gill proteomes and gene expression. However, the impacts of elevated $\mathrm{CO}_{2}$ and temperature were not additive or synergistic, and may be antagonistic.

Conclusions: The data suggest that the simultaneous exposure of $\mathrm{CO}_{2}$-resilient oysters to near-future projected ocean $\mathrm{pH}$ and temperature results in complex changes in molecular processes in order to prevent stress-induced cellular damage. The differential response of B2 oysters to the combined stressors also indicates that the addition of thermal stress may impair the resilience of these oysters to decreased $\mathrm{pH}$. Overall, this study reveals the intracellular mechanisms that might enable marine calcifiers to endure the emergent, adverse seawater conditions resulting from climate change.
\end{abstract}

Keywords: Climate change, Gene expression, Proteomics, Saccostrea glomerata, Selective breeding, Thermal stress, Low pH

\section{Background}

Environmental change in marine ecosystems resulting from global climate change represents one of the most serious threats to marine organisms. Oceans are becoming warmer and more acidic as atmospheric concentrations of $\mathrm{CO}_{2}$ increase [1]. Marine organisms will need to acclimate or adapt in the face of these shifts in seawater chemistry and temperature. Many studies have described the negative impacts of ocean acidification (OA) and

\footnotetext{
* Correspondence: priscilagoncalves.pg@gmail.com

'Department of Biological Sciences, Macquarie University, Sydney, NSW 2109, Australia

${ }^{2}$ Sydney Institute of Marine Science, Chowder Bay, Sydney, NSW 2088,

Australia

Full list of author information is available at the end of the article
}

rising temperatures on the calcification, energy metabolism, reproduction, development and growth of marine calcifiers, such as oysters [2-8]. For instance, under elevated $\mathrm{CO}_{2}$ conditions, oysters exhibit weaker shells [9], higher mortality rates and lower soft tissue growth [10], as well as impaired immune functions (e.g. increase in apoptosis and reactive oxygen species production) [11]. Such pervasive impacts may ultimately affect the survival and sustainability of entire populations, especially when coupled with a warmer ocean.

The impacts of $\mathrm{OA}$ and rising temperatures on oysters also extend to the intracellular level. Proteomic studies have shown that $\mathrm{CO}_{2}$-driven $\mathrm{OA}(\mathrm{pH} 7.3$ to $7.87 ; 856$ to $3000 \mu \mathrm{atm} p \mathrm{CO}_{2}$; 2- to 4-week exposure) alters the concentrations of proteins involved in antioxidant defence, 
stress responses, energy metabolism and the cytoskeleton in the oysters Crassostrea gigas (gills, hepatopancreas and larvae) [12-15], Crassostrea virginica (mantle) [16], Crassostrea hongkongensis (larvae) $[17,18]$ and Saccostrea glomerata (gills and hemocytes) [19, 20]. Similarly, transcriptional analysis of $C$. virginica oysters exposed to elevated $\mathrm{CO}_{2}$ (gill, mantle and hemocytes; $\mathrm{pH} 7.5$ to 7.6 ; 2000 to $3500 \mu$ atm $p \mathrm{CO}_{2}$; 2-week exposure) has identified changes in the expression of genes associated with calcification, stress and immune responses $[21,22]$. Increasing temperature also causes substantial changes in the molecular processes of marine organisms [23]. Heat shock proteins (Hsp) are one of the major protein families involved in the physiological response to thermal stress. Exposure to acute heat stress $\left(+15{ }^{\circ} \mathrm{C}\right.$ to $19{ }^{\circ} \mathrm{C}$ increases relative to current ambient conditions) has been shown to substantially increase (up to 2000fold) Hsp expression in the gills of the Pacific oyster $C$. gigas (up to $12 \mathrm{~h}$ exposure) [24, 25]. Acute heat stress $\left(+12{ }^{\circ} \mathrm{C}\right.$ relative to ambient) also induced changes in the transcriptional levels of other genes involved in cellular homeostasis and protein synthesis (gills and mantle; 324 day exposure) [26]. At the protein level, increased concentrations of Hsp, as well as changes in the concentrations of proteins involved in energy metabolism, calcium binding and immune responses, were observed in the gills of $C$. gigas following exposure to temperature extremes $\left(+20^{\circ} \mathrm{C}\right.$ relative to ambient; $1 \mathrm{~h}$ exposure) [27]. Although relevant given the broad temperature ranges oysters encounter in their natural environment, these studies have focused on acute heat stress $\left(+12{ }^{\circ} \mathrm{C}\right.$ to $20^{\circ}$ $\mathrm{C}$ relative to control) and so do not reflect near-future climate change scenarios where projected temperature increases span between $1.5{ }^{\circ} \mathrm{C}$ and $3.2{ }^{\circ} \mathrm{C}$ by the end of this century [1].

The transcriptomic response of oysters to a combination of low $\mathrm{pH}$ and increasing temperature has been assessed using next-generation sequencing (NGS) $[28,29]$. The authors found that $\mathrm{OA}$ and the combination of both OA and increasing temperature have distinct effects on the intracellular systems of $C$. virginica and $C$. gigas. OA enhanced the expression of genes involved in antioxidant and metabolic processes in the gills and hepatopancreas of C. virginica. Both OA (up to $-0.5 \mathrm{pH}$ units relative to control) and increasing temperature (up to $+3{ }^{\circ} \mathrm{C}$ relative to control) affected protein synthesis and processes involved in cell growth, as well as altering the expression of genes related to metabolism [29]. In the Pacific oyster, C. gigas, low $\mathrm{pH}(-0.4 \mathrm{pH}$ units relative to control) enhanced the expression of immune response genes and the production of antioxidants, while the combination of both $\mathrm{pH}$ and thermal stresses $\left(+5{ }^{\circ} \mathrm{C}\right.$ relative to control) induced the expression of protease inhibitors and cytoskeleton-related genes in mantle tissue [28].
Recent evidence also suggests that oysters may be able to rapidly acclimate or adapt to such stressful conditions $[6,30,31]$. Molluscs from naturally $\mathrm{CO}_{2}$ enriched environments do not show the physiological effects typically induced when they are experimentally exposed to elevated $\mathrm{CO}_{2}[6,31]$. Moreover, environmental stressors associated with climate change often elicit different phenotypic responses in distinct populations within a species. Populations of C. gigas selectively bred for tolerance to acute heat stress (higher survival rates during experimentally-induced summer mortality events) show distinctive transcriptional profiles relative to populations that are sensitive to rising temperatures [32]. These heat-tolerant oysters exhibited lower expression levels of Hsp27, collagen, peroxinectin and S-crystallin, and higher expression of cystatin $\mathrm{B}$ following heat shock $\left(+25{ }^{\circ} \mathrm{C}\right.$ relative to ambient; 1-24 h exposure; gill tissue).

Elevated $\mathrm{CO}_{2}$ concentrations have also been shown to induce differential physiological and intracellular responses in a genetically-distinct population of Sydney rock oysters (S. glomerata). The B2 breeding line represents a unique genetic resource because of its capacity to cope with the effects of $\mathrm{CO}_{2}$ stress at the physiological level [30, 33]. This breeding line has been produced through mass selection for faster growth and resistance to the most significant oyster diseases in Australia [34]. Surprisingly, artificial selection for these characteristics appears to have coincidentally resulted in resilience against $\mathrm{CO}_{2}$-driven $\mathrm{OA}[30,33]$. Larvae from the $\mathrm{B} 2$ breeding line have higher survival rates and grow faster than wild type (non-selected) larvae following exposure to elevated $\mathrm{CO}_{2}\left(\mathrm{pH} 7.90,856 \mu\right.$ atm $\left.p \mathrm{CO}_{2}\right)$ $[30,33]$. B2 adults have higher standard metabolic rates (SMR) than wild type oysters under ambient conditions, and their SMR is further increased by $\mathrm{CO}_{2}$ stress [30].

Differential responses between populations of Sydney rock oysters are also evident at the molecular level. Distinctive changes in protein and gene regulation were found in $\mathrm{B} 2$ oysters after exposure to elevated $\mathrm{CO}_{2}$ (625 to $856 \mu \mathrm{atm} p \mathrm{CO}_{2}$, resulting in $\mathrm{pH} 7.78$ to 7.84). Molecules involved in metabolism, oxidative stress, transcription, protein synthesis and modification, as well as signal transduction were the most affected by $\mathrm{CO}_{2}$-driven $\mathrm{OA}$ (gills and juvenile whole-body tissue) [19, 35]. The transgenerational responses of the $\mathrm{B} 2$ breeding line to $\mathrm{CO}_{2}$ stress have also been investigated at the level of gene expression. Exposure of $\mathrm{B} 2$ oysters to elevated $\mathrm{CO}_{2}$ over three consecutive generations (F2 juveniles) resulted in the up-regulation of genes associated with antioxidant defence, metabolism and the cytoskeleton (whole-body tissue) [35]. These findings suggest that the distinctive performance of B2 oysters might result from their 
capacity to regulate metabolic activity and control oxidative stress in face of elevated $\mathrm{CO}_{2}$ through differential regulation of molecules involved in these processes.

Despite the comprehensive characterisation of the responses of $\mathrm{B} 2$ oysters to near-future projected ocean $\mathrm{pH}$, particularly at the physiological level, little is known about how these $\mathrm{CO}_{2}$-resilient oysters will respond to more realistic future scenarios that combine OA with increasing temperature. The current study addressed this deficit by describing the molecular processes of B2 oysters that are affected by the combination of $\mathrm{OA}$ and increasing temperature at both the protein and transcriptional levels. In the current study, we investigated the interactive effects of $\mathrm{OA}$ and increasing temperature on the molecular response of B2 oysters using a combination of proteomics and transcriptional analysis. This work is the first to explore the heritable potential of oysters for acclimation or adaptation to both climate change variables at the molecular level. This understanding will be crucial for assessing the performance of marine calcifiers and the sustainability of their populations in a changing ocean. It will also aid the development of marker-assisted breeding programs designed to safeguard oyster aquaculture industries as climate change progresses.

\section{Methods}

Oysters and exposure to elevated $\mathrm{CO}_{2}$ and temperature Adult Sydney rock oysters (Saccostrea glomerata; Gould 1850) from the B2 breeding line were kindly provided by the Port Stephens Fisheries Institute (PSFI, Taylors Beach, NSW, Australia) of the New South Wales (NSW) Department of Primary Industries (DPI). The B2 breeding line has been bred for faster growth and resistance to the most significant oyster diseases in Australia: QX disease (causative agent: Marteilia sydneyi) and winter mortality syndrome (causative agent is currently under review [36]) [34]. Progenitors of the B2 line were established from parents collected from four rivers in NSW that had been affected by severe annual outbreaks of QX disease [37]. The breeding line has been produced by mass selection where fast growing survivors of disease epizootics are selected as parents for subsequent generations. The oysters used in this study were from the sixth generation of the B2 line. Surprisingly, this artificial selection for fast growth and disease resistance in the $\mathrm{B} 2$ line appears to have coincidentally conferred resilience against $\mathrm{CO}_{2}$-driven $\mathrm{OA}$, such that $\mathrm{B} 2$ oysters can better withstand the impacts of elevated $\mathrm{CO}_{2}$ at the physiological level, compared to non-selected $S$. glomerata [30, 33].

Oysters $(6.63 \pm 0.71 \mathrm{~cm}$ shell length) were transferred to the Sydney Institute of Marine Science (Chowder Bay, NSW) and acclimated to aquarium conditions in a flow-through seawater system $(0.5 \mathrm{~L}$ per minute, seawater filtered at $20 \mu \mathrm{m}$; corresponding to ambient conditions in Table 1). The nutritional supply from the flow-through seawater was supplemented every 3 days with a concentrated blend of microalgae (Shellfish Diet ${ }^{\oplus}$ 1800, Reed Mariculture Inc., $4.3 \times 10^{8}$ algal cells per oyster). Following a 10 day acclimation, B2 oysters were exposed for 1 month to combinations of ambient $\left(495 \mu\right.$ atm $p \mathrm{CO}_{2}$, $\mathrm{pH}$ 8.09) or near-future elevated (1276 $\mu$ atm $p \mathrm{CO}_{2}$, $\mathrm{pH}$ 7.72) $\mathrm{CO}_{2}$ concentrations with ambient $\left(22.11{ }^{\circ} \mathrm{C}\right)$ or near-future elevated $\left(25.38{ }^{\circ} \mathrm{C}\right)$ temperatures (Table 1). The elevated $\mathrm{CO}_{2}$ (mean decrease of $0.37 \mathrm{pH}$ units) and temperature (mean increase of $3.26{ }^{\circ} \mathrm{C}$ ) conditions are based on projected ocean surface increases by the year 2100 [1]. Seawater $\mathrm{CO}_{2}$ concentrations and temperatures were controlled by a custom-made system that included pneumatic components from Parker Hannifin (Castle Hill, NSW), $\mathrm{CO}_{2}$ sensors from Vaisala (Hawthorn, VIC) and a control system from Greenstar Building Automation \& Citywide Electrical Services (Marrickville, NSW). $\mathrm{CO}_{2}$ enriched air and heated water were added into two header tanks, which supplied the treatments with reduced $\mathrm{pH}$ (elevated $\mathrm{CO}_{2}$ ). Each treatment comprised three replicate tanks $(45 \mathrm{~L})$, each of which contained 7 oysters $(n=21$ oysters per treatment). Temperature,

Table 1 Seawater chemistry during ocean acidification and warming trial

\begin{tabular}{|c|c|c|c|c|}
\hline \multirow[t]{2}{*}{ Parameter } & \multicolumn{4}{|l|}{ Treatments } \\
\hline & $\mathrm{aCO}_{2}+\mathrm{aT}$ & $\mathrm{aCO}_{2}+\mathrm{eT}$ & $\mathrm{eCO}_{2}+\mathrm{aT}$ & $\mathrm{eCO}_{2}+\mathrm{eT}$ \\
\hline $\mathrm{pH}$ & $8.10 \pm 0.02$ & $8.08 \pm 0.02$ & $7.70 \pm 0.06$ & $7.74 \pm 0.08$ \\
\hline Temperature $\left({ }^{\circ} \mathrm{C}\right)$ & $22.23 \pm 0.16$ & $25.86 \pm 0.17$ & $21.99 \pm 0.30$ & $24.90 \pm 0.57$ \\
\hline Salinity (ppt) & $33.84 \pm 0.02$ & $33.84 \pm 0.13$ & $33.83 \pm 0.45$ & $33.83 \pm 0.52$ \\
\hline Total alkalinity $\left(\mathrm{mmol} \mathrm{kg}{ }^{-1} \mathrm{sW}\right)$ & $2.20 \pm 0.02$ & $2.20 \pm 0.03$ & $2.15 \pm 0.03$ & $2.14 \pm 0.04$ \\
\hline$p \mathrm{CO}_{2}$ ( $\left.\mu \mathrm{atm}\right)$ & $473.5 \pm 20.6$ & $516.6 \pm 22.3$ & $1329.8 \pm 181.2$ & $1222.5 \pm 210.9$ \\
\hline
\end{tabular}

Salinity, temperature and pH (NBS scale) were determined using a YSI 63 probe. Total alkalinity was measured in an automatic titrator (Metrohm 888 Titrando) and $p \mathrm{CO}_{2}$ was calculated using co2sys software [33]. Data are presented as mean \pm SD ( $n=66$ per treatment; 3 tanks $\times 22$ days). Abbreviations: $a$ ambient, $e$ elevated, $T$ temperature 
salinity and carbonate parameters ( $\mathrm{pH}$ and total alkalinity) of seawater were monitored throughout the experiment (Table 1).

The experimental exposures produced a total of four treatments: $\mathrm{aCO}_{2}+\mathrm{aT}$ (ambient $\mathrm{CO}_{2}$ and ambient temperature), $\mathrm{aCO}_{2}+\mathrm{eT}$ (ambient $\mathrm{CO}_{2}$ and elevated temperature), $\mathrm{eCO}_{2}+\mathrm{aT}$ (elevated $\mathrm{CO}_{2}$ and ambient temperature), and $\mathrm{eCO}_{2}+\mathrm{eT}$ (elevated $\mathrm{CO}_{2}$ and elevated temperature). Following the one-month exposure to $\mathrm{CO}_{2}$ and/or thermal stress, oyster gills were collected and used for both proteomics and transcriptomics. Gills are amongst the tissues most immediately affected by changes in seawater quality, because they are metabolically active and represent the key interface between the organism and its environment. In addition, gill tissue is a tractable source of high quality RNA and protein in oysters. Hence, they have been used for proteomic and transcriptomic analyses in numerous previous studies (e.g. [12, 21, 27, 29]). For proteomics, oyster gills were immediately frozen at $-80{ }^{\circ} \mathrm{C}(n=15$ per treatment), while gill samples for transcriptional analysis were stored in RNA later (Ambion) at $-20{ }^{\circ} \mathrm{C}(n=21$ per treatment; including same oysters used for proteomics).

\section{RNA extraction and CDNA synthesis}

Total RNA was extracted from approximately $100 \mathrm{mg}$ of gill tissue ( $n=21$ oysters per treatment; individually sampled and processed) using TRI Reagent (Sigma-Aldrich), according to the manufacturer's protocol. RNA was treated with DNase I (Promega) and further precipitated with $0.3 \mathrm{M}$ sodium acetate ( $\mathrm{pH}$ 5.5) and isopropanol. Concentration and quality of total RNA were checked with a Nanodrop spectrophotometer (Thermo Scientific NanoDrop 2000). Complementary DNA (cDNA) was synthesized from $1 \mu \mathrm{g}$ of total RNA using ImProm- $\mathrm{II}^{\mathrm{IM}}$ Reverse Transcription System (Promega) and $0.5 \mu \mathrm{g}$ of oligo $(\mathrm{dT})_{15}$ in a $20 \mu$ l reaction volume.

\section{qPCR analysis}

The transcriptional responses of B2 oysters to ocean acidification and warming were investigated by assessing the expression profiles of 60 genes involved in multiple biological processes. These genes were selected based on a previous study that explored the transcriptome of B2 oysters exposed to elevated $\mathrm{CO}_{2}$ (Goncalves et al., in preparation). Primers for quantitative (q) PCR analysis were designed to amplify the contigs most affected by ocean acidification (highest up- or down-regulation) (Additional file 1: Table S1).

Three microliter qPCR reactions were prepared in duplicate in 384-well plates using an epMotion ${ }^{\circ} 5075$ pipetting robot (Eppendorf) and an Echo 550 Liquid Handler (Labcyte). Each reaction contained $1.5 \mu \mathrm{l}$ KAPA SYBR $^{\circledR}$ FAST qPCR Master Mix (Kapa Biosystems),
$300 \mathrm{nM}$ each primer, $0.3 \mu \mathrm{l}$ PCR grade water and $1 \mu \mathrm{l}$ cDNA template (diluted 1:9). qPCR assays were carried out on a LightCycler 480 II (Roche). The cycling program used consisted of $3 \mathrm{~min}$ at $95^{\circ} \mathrm{C}$ followed by $45 \mathrm{cy}$ cles of $95{ }^{\circ} \mathrm{C}$ for $10 \mathrm{~s}, 60{ }^{\circ} \mathrm{C}$ for $20 \mathrm{~s}$ and $72{ }^{\circ} \mathrm{C}$ for $6 \mathrm{~s}$. At the end of the qPCR cycles, melting curve analysis was performed by collecting fluorescence data between 65 and $95{ }^{\circ} \mathrm{C}$ at $0.5{ }^{\circ} \mathrm{C}$ increments. Reaction efficiencies were calculated from standard curves generated in triplicate for each primer pair using five four-fold serial dilutions of a pool of cDNA samples (Additional file 1: Table S1). Cq values were obtained using the LightCycler 480 Real-Time PCR System (version 1.5.1.62).

Gene expression stability of three potential reference genes was evaluated using the web-based RefFinder platform, which integrates results from different software tools [38]. Elongation factor 1 alpha (EF1 $\alpha), \beta$-actin and GAPDH were previously found to be stable under $\mathrm{CO}_{2}$ stress [35] and thus were tested in the current study. The geometric mean of these three genes combined were found to be the most stable combination (compared to each gene used individually or in pairs) and so all three genes were used as references (geNorm stability value $=0.102$; NormFinder stability value $=0.051$; Stability value by $\Delta \mathrm{Ct}$ method / Average $\mathrm{SD}=0.17$; BestKeeper stability value $=0.251$ ). $\mathrm{qPCR}$ data are presented as changes in relative expression normalised with the geometric mean of the $\mathrm{Cq}$ values of $\mathrm{EF} 1 \alpha, \beta$-actin and GAPDH [39].

\section{Protein extraction}

Proteins were isolated from approximately $100 \mathrm{mg}$ of gill tissue ( $n=15$ per treatment; individually sampled and processed) using $1 \mathrm{ml}$ of TRI Reagent (Sigma-Aldrich), according to the manufacturer's protocol. After removal of RNA and DNA fractions, proteins were precipitated with acetone ( $3 \times$ volume) for $10 \mathrm{~min}$ followed by centrifugation for $10 \mathrm{~min}$ at $12000 \times \mathrm{g}\left(4{ }^{\circ} \mathrm{C}\right)$. The resulting protein pellet was purified by multiple washes, following the protocol previously described by [19], with slight modifications. Briefly, protein pellets were washed by adding $1 \mathrm{ml}$ of $0.3 \mathrm{M}$ guanidine hydrochloride in $95 \%$ ethanol $(3 \times 10 \mathrm{~min}$, room temperature) before centrifugation at $8000 \times \mathrm{g}\left(4{ }^{\circ} \mathrm{C}\right)$. A final wash was carried out with $95 \%$ ethanol for $10 \mathrm{~min}$ followed by centrifugation as above. Protein pellets were air dried at room temperature and resuspended in $50 \mu \mathrm{l}$ of rehydration buffer (7 M urea, $2 \mathrm{M}$ thiourea, 4\% CHAPS, $50 \mathrm{mM}$ DTT and bromophenol blue).

Once purified, protein samples were quantified using Bradford reagent (Sigma-Aldrich) with BSA as the standard [40]. Equivalent amounts of proteins $(30 \mu \mathrm{g})$ were pooled from five oysters taken from the same 
exposure tank, resulting in three biological replicates per treatment (3 pools of 5 oysters each per treatment) and twelve $2 \mathrm{D}$-gels across the four treatments $(150 \mu \mathrm{g}$ protein per gel).

\section{D gel electrophoresis}

The proteomic responses of B2 oysters to ocean acidification and warming were assessed by two-dimensional gel electrophoresis (2DE). A total of three gels were run per treatment (representing each of the three replicate tanks per treatment). Proteins ( $150 \mu \mathrm{g}$ in $125 \mu \mathrm{l}$ of rehydration buffer containing $0.2 \%$ pharmalytes) were immobilised in $\mathrm{pH}$ linear gradient gel strips $(7 \mathrm{~cm}$, pH 4-7; ReadyStrip ${ }^{\text {th }}$ IPG Strips, Bio-Rad) by overnight passive rehydration. Isoelectric focusing (IEF) was performed using an IPGphor IEF System (GE Healthcare) at $100 \mathrm{~V}$ for $2 \mathrm{~h}, 250 \mathrm{~V}$ for $20 \mathrm{~min}$, a gradient up to $5000 \mathrm{~V}$ for $2 \mathrm{~h}$ and then $5000 \mathrm{~V}$ for $2 \mathrm{~h}$. Following IEF, gel strips were equilibrated for $20 \mathrm{~min}$ in equilibration buffer I (1\% DTT, $75 \mathrm{mM}$ of $1.5 \mathrm{M}$ Tris- $\mathrm{HCl} \mathrm{pH} 8.8$, $6 \mathrm{M}$ urea, 30\% glycerol, 2\% SDS, bromophenol blue) and then for $20 \mathrm{~min}$ in equilibration buffer II $(2.5 \%$ iodoacetamide instead of $1 \%$ DTT in equilibration buffer I). Second dimension separation was conducted using 12\% Mini-PROTEAN ${ }^{\star}$ TGX $^{\mathrm{T}}$ Precast Protein Gels (Bio-Rad) in a Mini-PROTEAN ${ }^{\circ}$ Tetra Vertical Electrophoresis System (Bio-Rad). After electrophoresis, gels were stained with blue silver [41] and visualised using a ChemiDoc XRS+ (Bio-Rad). Quantitative image analysis of protein spots was performed by PDQuest 2-D Analysis Software (Bio-Rad).

\section{In-gel digestion of differentially regulated proteins}

The protein spots found to be differentially regulated by elevated $\mathrm{CO}_{2}$ and/or elevated temperature were excised manually and subjected to in-gel digestion. A fresh set of 2D gels was used for spot picking. Gel pieces were washed with $100 \mathrm{mM}$ ammonium bicarbonate and then destained with $50 \%$ acetonitrile in $50 \mathrm{mM}$ ammonium bicarbonate (multiple washes for $10 \mathrm{~min}$ each). Following destaining, gel pieces were dehydrated in 100\% acetonitrile for $5 \mathrm{~min}$ before being air dried. They were then reduced with $10 \mathrm{mM}$ DTT in $100 \mathrm{mM}$ ammonium bicarbonate at $56{ }^{\circ} \mathrm{C}$ for $1 \mathrm{~h}$, alkylated with $55 \mathrm{mM}$ iodoacetamide in $100 \mathrm{mM}$ ammonium bicarbonate $(45 \mathrm{~min}$ at room temperature) and further washed and dehydrated as above. Trypsin $(12.5 \mathrm{ng} / \mu \mathrm{l}$ in $50 \mathrm{mM}$ ammonium bicarbonate; Promega) was added to each gel piece and the mixture was incubated first for $30 \mathrm{~min}$ at $4{ }^{\circ} \mathrm{C}$ and then overnight at $37{ }^{\circ} \mathrm{C}$. After overnight digestion, gel pieces were washed twice in $50 \%$ acetonitrile and $2 \%$ formic acid for $30 \mathrm{~min}$ to recover the peptide-containing supernatant (50 to $60 \mu \mathrm{l}$ final volume). Supernatants were concentrated to $12 \mu \mathrm{l}$ in a vacuum concentrator (Concentrator Plus,
Eppendorf) and then centrifuged at $12000 \times \mathrm{g}$ for $10 \mathrm{~min}$ to remove microparticles.

\section{Protein characterisation by mass spectrometry}

Trypsin-digested peptides were analysed by nanoflow liquid chromatography-tandem mass spectrometry (LC-MS/MS) using a Finnigan Surveyor MS Pump Plus coupled to a Finnigan LTQ $\mathrm{XL}^{\mathrm{mm}}$ Linear Ion Trap Mass Spectrometer (Thermo Scientific). Chromatography was performed in reversed-phase peptide trap columns packed to approximately $9 \mathrm{~cm}(100 \mu \mathrm{m}$ ID) with Magic C18AQ $(5 \mu \mathrm{m}, 200 \AA$, Michrom Bioresources), in a fused silica capillary with an integrated electrospray tip, coupled to pre-columns packed with PS-DVB resin $(3 \mathrm{~cm}, 100 \mu \mathrm{m}$ ID, Agilent Technologies). A $1.8 \mathrm{kV}$ electrospray voltage was applied through a liquid junction up-stream of the C18 column. Sample injection was carried out using an EASY-nLC II (Thermo Scientific). Peptides were washed with buffer A (2\% acetonitrile, $0.1 \%$ formic acid) for $2 \mathrm{~min}$ at $140 \mathrm{nl} / \mathrm{min}$ and then eluted from the column with $0-20 \%$ gradient of buffer B $(95 \%$ acetonitrile, $0.1 \%$ formic acid) at $140 \mathrm{nl} / \mathrm{min}$ for $38 \mathrm{~min}$. Following peptide elution, the column was washed with $95 \%$ buffer B at $140 \mathrm{nl} / \mathrm{min}$ for $10 \mathrm{~min}$. Spectra were acquired for $60 \mathrm{~min}$ in positive ion mode for the scan range of $400 \mathrm{~m} / \mathrm{z}$ to $1500 \mathrm{~m} / \mathrm{z}$. Automated peak recognition, dynamic exclusion and MS/MS of the top nine most intense precursor ions at $35 \%$ normalisation collision energy were performed using Xcalibur ${ }^{\mathrm{Tm}}$ software (version 2.06, Thermo Scientific).

Mass spectrometry data files were analysed using Global Proteome Machine (GPM) software (version 2012.05.01) and the X!Tandem algorithm [42, 43]. Files were searched against a non-redundant (nr) protein database for Mollusca (downloaded from NCBI in March 2015), using default settings. The Mollusca nr database contained 378,914 sequences, including those derived from the C. gigas genome, in addition to common human and trypsin peptide contaminants. Spectra were also searched against a reversed sequence database for estimation of false discovery rates (FDR). Peptides that yielded $\log (\mathrm{e})$ values $\leq-10$ and at least five spectral counts were retained for protein characterisation.

\section{Statistical analyses}

The statistical significance of differences between treatments for proteomic and transcriptional data was assessed by a linear model, considering the ambient control condition as the reference $(p<0.05)$, and by the significance analysis of microarrays (SAM; FDR $<10 \%$ ). Statistical analysis on proteomic data was performed on the normalised intensities of protein spots from $2 \mathrm{D}$ gels. 
Relative gene expression data used for statistical analysis were calculated by normalising $\mathrm{Cq}$ values of each target gene with the geometric mean of the Cq values of EF1 $\alpha$, $\beta$-actin and GAPDH (reference genes) [39]. Tests were carried out using the mean response of oysters from the same exposure tank, such that each of the 3 tanks per treatment was considered to be an independent biological replicate. Three tanks per treatment each containing a pool of 5 oysters were used for proteomic analysis, while 3 tanks per treatment each containing 7 oysters (individual samples) were used for gene expression analysis.

Fold differences for each differentially expressed protein or gene were determined by comparing the mean normalised protein spot intensities or mean relative expression of each treatment where at least one parameter $\left(\mathrm{CO}_{2}\right.$ or temperature) was elevated relative to those of ambient control conditions $\left(\mathrm{aCO}_{2}+\mathrm{aT}\right)$. Fold change (FC) values $>1$ reflect up-regulation in the elevated treatment relative to ambient controls. FC values $<1$ reflect down-regulation in the elevated treatment. Differences between $\mathrm{CO}_{2}$ and temperature conditions were also visualised in non-metric multi-dimensional scaling (NMDS) plots. NMDS was based on Bray-Curtis similarity coefficients calculated from normalised intensities of differentially regulated proteins or differentially expressed genes (absolute fold-change $\geq 1.5$ ).

Differences in seawater parameters (temperature, $\mathrm{pH}$, $p \mathrm{CO}_{2}$, salinity and total alkalinity) between the elevated treatments were assessed by Student's $t$ test, comparing the conditions in tanks sharing the same elevated parameter (e.g. elevated $\mathrm{CO}_{2}+$ ambient temperature vs. elevated $\mathrm{CO}_{2}+$ elevated temperature treatment; and ambient $\mathrm{CO}_{2}+$ elevated temperature vs. elevated $\mathrm{CO}_{2}+$ elevated temperature).

\section{Results}

Experimental conditions for exposure to $O A$ and warming Seawater chemical and physical parameters were assessed throughout the experimental exposures (Table 1). Tanks for elevated $\mathrm{CO}_{2}$ and for elevated temperature treatments were supplied by independent seawater reservoirs, which resulted in differences in $\mathrm{pH}$ and temperature among treatments. Such variation in $\mathrm{pH}$ and temperature was also reflected by small differences in seawater carbonate chemistry, since $p \mathrm{CO}_{2}$ concentration was calculated based upon measurements of these two variables (in addition to salinity and total alkalinity, which did not show significant variability). Seawater $\mathrm{pH}$ was 0.04 units lower in elevated $\mathrm{CO}_{2}+$ ambient temperature $\left(\mathrm{eCO}_{2}+\mathrm{aT}\right)$ relative to the elevated $\mathrm{CO}_{2}+$ elevated temperature treatment $\left(\mathrm{eCO}_{2}+\mathrm{eT}\right)$ ( $p=0.04$, two-tailed t-test). As a result, $p \mathrm{CO}_{2}$ concentration was higher $(+107 \mu \mathrm{atm})$ in elevated $\mathrm{CO}_{2}+$ ambient temperature $\left(\mathrm{eCO}_{2}+\mathrm{aT}\right)$ tanks relative to the elevated $\mathrm{CO}_{2}+$ elevated temperature condition $\left(\mathrm{eCO}_{2}+\mathrm{eT}\right)$ (Table 1). However, this difference in $p \mathrm{CO}_{2}$ concentrations between the elevated $\mathrm{CO}_{2}$ treatments was not statistically significant $(p=0.08$, two-tailed $\mathrm{t}$ test).

Similar variation was also evident between the elevated temperature treatments. Tanks for ambient $\mathrm{CO}_{2}+$ elevated temperature $\left(\mathrm{aCO}_{2}+\mathrm{eT}\right)$ and elevated $\mathrm{CO}_{2}+$ elevated temperature $\left(\mathrm{eCO}_{2}+\mathrm{eT}\right)$ were also supplied by independent flow-through seawater systems, which led to differences in temperature between treatments. Tanks for ambient $\mathrm{CO}_{2}+$ elevated temperature $\left(\mathrm{aCO}_{2}+\mathrm{eT}\right)$ treatment were $0.96{ }^{\circ} \mathrm{C}$ warmer than those for elevated $\mathrm{CO}_{2}+$ elevated temperature $\left(\mathrm{eCO}_{2}+\mathrm{eT}\right)(p=3.88 \mathrm{e}-11$, two-tailed t-test) (Table 1).

\section{Molecular profiles of oysters in response to ocean acidification and warming}

Ocean acidification (OA) and warming induced substantial changes in the proteomes and gene expression of B2 oysters. The differential proteomes of oysters in response to elevated $\mathrm{CO}_{2}$ and/or elevated temperature were resolved by $2 \mathrm{D}$ gel electrophoresis. An average of 345 protein spots was detected across the 2D gels, with molecular weights (MW) ranging from 12 to $200 \mathrm{kDa}$ and isoelectric points (pI) ranging from 4 to 7 .

Of the 345 protein spots identified, 39 were found to differ significantly in intensity $(p<0.05$ or FDR $<10 \%)$ in at least one of the elevated $\mathrm{CO}_{2}$ and/or elevated temperature treatments, relative to control conditions $\left(\mathrm{aCO}_{2}+\mathrm{aT}\right)$. Of these, three differential proteins were common to all three elevated treatments $\left(\mathrm{aCO}_{2}+\mathrm{eT}\right.$, $\mathrm{eCO}_{2}+\mathrm{aT}$ and $\mathrm{eCO}_{2}+\mathrm{eT}$ ), while 27 were unique to particular treatments. Of these, most $(19 ; 70 \%)$ were unique to the elevated $\mathrm{CO}_{2}+$ ambient temperature treatment $\left(\mathrm{eCO}_{2}+\mathrm{aT}\right)$ (Fig. 1a). Mass spectrometry was performed on 36 differentially regulated proteins (proteins spots are highlighted in Fig. 2a). Twenty-three proteins (64\%) were successfully identified based on homology to a Mollusca non-redundant (nr) database (Additional file 2: Table S2).

The transcriptional responses of B2 oysters to elevated $\mathrm{CO}_{2}$ and/or elevated temperature were analysed by qPCR. We evaluated the relative expression profiles of 60 genes that have been previously shown to be differentially regulated following transgenerational exposure of B2 oysters to $\mathrm{CO}_{2}$ stress (Goncalves et al., in preparation). Twenty-one genes (35\%) were found to be affected by one or both stresses (elevated $\mathrm{CO}_{2}$ and/or elevated temperature). Figure $1 \mathrm{~b}$ shows the number of differentially expressed genes that were unique to particular treatments and those that were affected by one or 

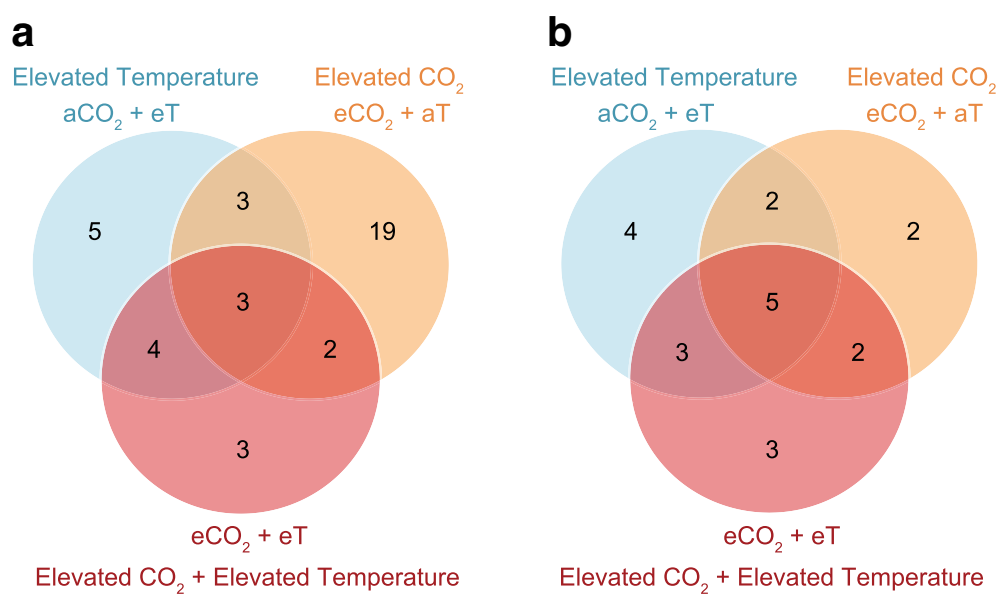

Fig. 1 Effects of ocean acidification and warming on the molecular responses of oysters. Venn diagrams showing the number of proteins (a) and genes (b) that were differentially regulated in oyster gills in response to elevated $\mathrm{CO}_{2}$ and/or elevated temperature. Differential regulation was determined by comparing spot normalised intensities or relative gene expression between each treatment and the control, ambient condition. $\mathrm{aCO}_{2}+$ eT: ambient $\mathrm{CO}_{2}$ and elevated temperature; $\mathrm{eCO}_{2}+\mathrm{aT}$ : elevated $\mathrm{CO}_{2}$ and ambient temperature; and eCO + eT: elevated $\mathrm{CO}_{2}$ and elevated temperature

more treatments. Five differentially regulated genes were common to all three elevated treatments $\left(\mathrm{aCO}_{2}+\mathrm{eT}\right.$, $\mathrm{eCO}_{2}+\mathrm{aT}$ and $\mathrm{eCO}_{2}+\mathrm{eT}$ ), while nine were unique to particular treatments.

\section{Effects of ocean acidification}

The exposure of oysters to elevated $\mathrm{CO}_{2}$ altered the expression of numerous individual proteins and genes. This is reflected by the clear spatial discrimination of cumulative protein and gene expression profiles between $\mathrm{CO}_{2}$-exposed oysters $\left(\mathrm{eCO}_{2}+\mathrm{aT}\right)$ and the other treatments (Fig. 2b and Fig. 3a). Elevated $\mathrm{CO}_{2}$ by itself $\left(\mathrm{eCO}_{2}+\mathrm{aT}\right)$ significantly affected the expression of 27 proteins and 11 transcripts (relative to $\mathrm{aCO}_{2}+\mathrm{aT}$ ). (Fig. 1). This represented the highest number of differentially regulated proteins among all of the $\mathrm{CO}_{2}$ and temperature treatments. NMDS plot incorporating data for differential proteins reveals that the $\mathrm{eCO}_{2}+\mathrm{aT}$ treatment had the most substantial response relative to ambient controls $\left(\mathrm{aCO}_{2}+\mathrm{aT}\right)$ (Fig. 2b). The majority of differentially regulated proteins (63\%) and genes (64\%) were less abundant in $\mathrm{eCO}_{2}+\mathrm{aT}$ oysters relative to the control treatment $\left(\mathrm{aCO}_{2}+\mathrm{aT}\right)$. In this comparison, the proteins found in lower abundance included actin (0.23-fold), ferritin (0.33-fold), cytochrome b5 (0.40fold), vacuolar protein sorting-associated protein $13 \mathrm{~A}$ (VPS13A; 0.49-fold) and Rho GDP dissociation inhibitor 1 (Rho-GDI; 0.50-fold) (Fig. 2c). Similarly, genes encoding von Willebrand factor D (VWF) and EGF domain-containing protein (0.17-fold), structural maintenance of chromosomes protein 3 (SMC3; 0.27-fold), multiple epidermal growth factor-like domains protein 10 (MEGF10; 0.36-fold), dual oxidase (0.54-fold) and heat shock $70 \mathrm{kDa}$ protein 12a (Hsp70a; 0.57-fold) were downregulated by $\mathrm{CO}_{2}$ stress (Fig. 3b).

Few proteins and genes were up-regulated by elevated $\mathrm{CO}_{2}$ alone $\left(\mathrm{eCO}_{2}+\mathrm{aT}\right)$. Heterogeneous nuclear ribonucleoprotein Q (hnRNP Q; 2.66-fold), nucleoside diphosphate kinase-like protein 5 (NDK5; 2.51-fold), 14-3-3 protein (2.26-fold), septin 2 (2.15-fold) and sperm associated antigen 6 (SPAG6; 2.00-fold) were found at higher concentrations in $\mathrm{eCO}_{2}+\mathrm{aT}$ oysters when compared to the $\mathrm{aCO}_{2}+\mathrm{aT}$ treatment (Fig. 2c). At the transcriptional level, extracellular superoxide dismutase (ecSOD; 2.46fold), cytochrome P450 CYP1A1 (6.88-fold), pentraxin fusion protein (2.44-fold) and hemagglutinin/amebocyte aggregation factor (HAAF; 1.83-fold) had higher expression levels in $\mathrm{CO}_{2}$-exposed oysters relative to controls (Fig. 3b).

\section{Effects of ocean warming}

Thermal stress by itself $\left(\mathrm{aCO}_{2}+\mathrm{eT}\right)$ also affected the gill proteomes and transcriptional responses of $\mathrm{B} 2$ oysters. Oysters exposed to elevated temperature alone $\left(\mathrm{aCO}_{2}+\mathrm{eT}\right)$ exhibited protein and gene expression profiles that were clearly different from those of oysters held under ambient conditions $\left(\mathrm{aCO}_{2}+\mathrm{aT}\right)$ and oysters exposed to elevated $\mathrm{CO}_{2}$ alone $\left(\mathrm{eCO}_{2}+\mathrm{aT}\right)$ (Fig. $2 \mathrm{~b}$ and Fig. 3a). The transcriptional response of $\mathrm{aCO}_{2}+\mathrm{eT}$ oysters was also distinct from the combined $\mathrm{eCO}_{2}+\mathrm{eT}$ treatment (Fig. 3a). However, this distinction was less apparent in their proteomic responses. NMDS of differentially regulated proteins showed substantial overlap between the $\mathrm{aCO}_{2}+\mathrm{eT}$ and $\mathrm{eCO}_{2}+$ eT treatments (Fig. 2b).

Elevated temperature alone $\left(\mathrm{aCO}_{2}+\mathrm{eT}\right)$ altered the regulation of 15 proteins and 14 genes, affecting a greater number of genes compared to elevated $\mathrm{CO}_{2}$ 

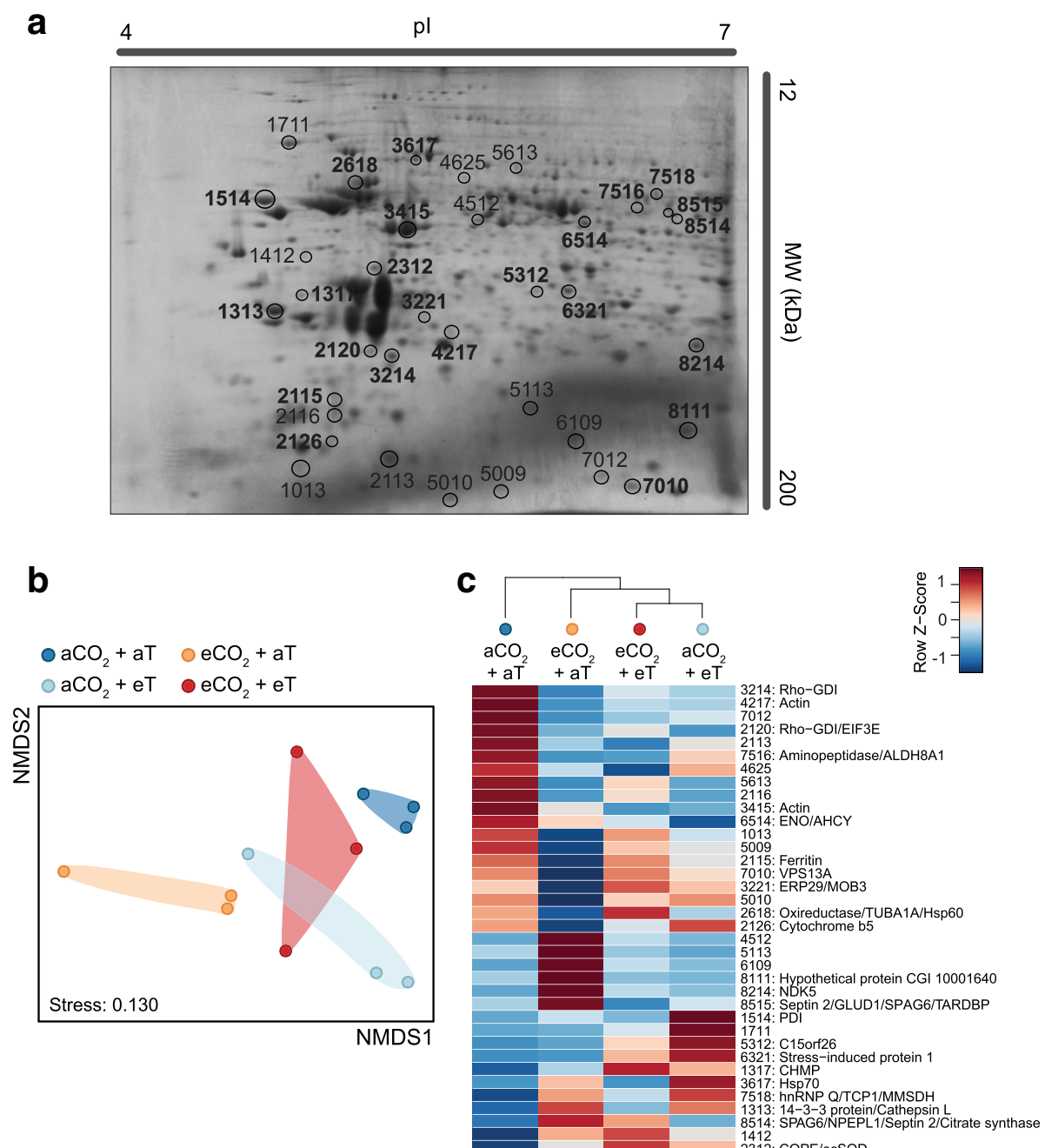

Fig. 2 Proteomic responses of oysters to ocean acidification and warming. a A representative gill proteome map of B2 line oysters. Protein spots differentially regulated due to $\mathrm{pH}$ and/or temperature treatments are highlighted. Numbers associated with each protein spot correspond to arbitrary identifiers generated by PDQuest during image analysis. Numbers in bold indicate the 23 protein spots that were successfully identified by mass spectrometry. pl, isoelectric point; MW, molecular weight in $\mathrm{kDa}$. b Non-metric multidimensional scaling (NMDS) plot summarising the cumulative normalised intensities of 23 differentially regulated protein spots among B2 oysters exposed to elevated $\mathrm{CO}_{2}$ and/or elevated temperature (T). Each point represents the spot intensity levels of pooled samples containing 5 oysters each per condition. $\mathbf{c}$ Heat map of mean normalised intensities of differentially regulated proteins. Proteins are identified by their spot numbers followed by their putative identifications obtained using mass spectrometry. Protein names and fold differences are detailed in Additional file 2: Table S2. aCO + aT: ambient $\mathrm{CO}_{2}$ and ambient temperature; $\mathrm{aCO}_{2}+\mathrm{eT}$ : ambient $\mathrm{CO}_{2}$ and elevated temperature; $\mathrm{eCO}_{2}+\mathrm{aT}$ : elevated $\mathrm{CO}_{2}$ and ambient temperature; and eCO + eT: elevated $\mathrm{CO}_{2}$ and elevated temperature

alone (Fig. 1). Most of the differentially regulated proteins $(60 \%)$ and genes $(79 \%)$ were found at lower concentrations in oysters exposed to elevated temperature $\left(\mathrm{aCO}_{2}+\mathrm{eT}\right)$ relative to control conditions $\left(\mathrm{aCO}_{2}+\mathrm{aT}\right)$. In this comparison, down-regulated proteins included enolase (0.42-fold), Rho-GDI (0.49-fold) and actin (0.51fold) (Fig. 2c), while uracil-DNA glycosylase (UDG; 0.42fold), dual oxidase (0.44-fold) and Hsp70 (0.42-fold for Hsp70a; 0.49-fold for Hsp70b) were among the downregulated transcripts (Fig. 3b). Conversely, protein disulphide isomerase (PDI; 3.85-fold) and stress-induced protein 1 (2.50-fold) were found in higher concentrations following heat stress (Fig. 2c), as well as the transcripts encoding CYP1A1 (3.93-fold), histone H4 (2.20-fold) and HAAF (1.64-fold) (Fig. 3b).

\section{Combined effects of ocean acidification and warming}

Oysters exposed to both elevated $\mathrm{CO}_{2}$ and elevated temperature $\left(\mathrm{eCO}_{2}+\mathrm{eT}\right)$ exhibited a unique gene expression profile that was different from all other treatments (Fig. 3a). Conversely, the differential proteomes of oysters exposed to both $\mathrm{CO}_{2}$ and heat stresses 
a

$$
\begin{array}{ll}
-\mathrm{aCO}+\mathrm{aT} & \circ \mathrm{eCO}_{2}+\mathrm{aT} \\
-\mathrm{aCO}_{2}+\mathrm{eT} & \bullet \mathrm{eCO}_{2}+\mathrm{eT}
\end{array}
$$

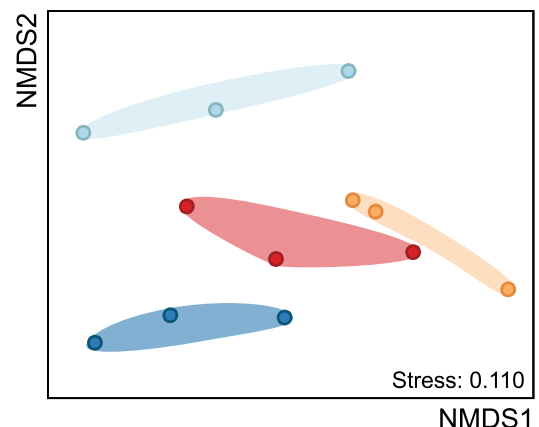

b

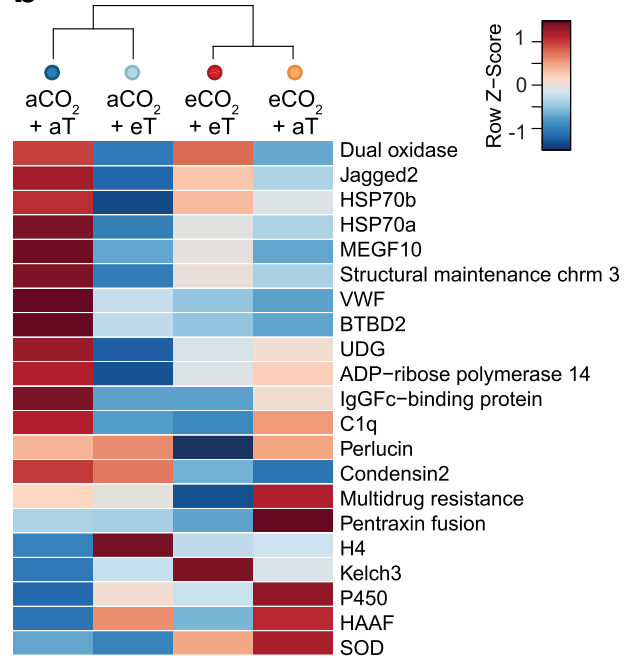

Fig. 3 Transcriptional responses of oysters to ocean acidification and warming. a Non-metric multidimensional scaling (NMDS) plot showing the cumulative expression profiles of differentially regulated genes among B2 oysters (gill tissue) exposed to elevated $\mathrm{CO}_{2}$ and/or elevated temperature (T). Each point represents the mean relative expression levels of oysters from the same exposure tank (average of 7 oysters for each of the 3 exposure tanks per condition). $\mathbf{b}$ Heat map of mean relative expression of differentially regulated genes assessed by qPCR. Gene names and their associated cellular functions are detailed in Additional file 1: Table S1. $\mathrm{aCO}_{2}+\mathrm{aT}$ : ambient $\mathrm{CO}_{2}$ and ambient temperature; $\mathrm{aCO}$ + eT: ambient $\mathrm{CO}_{2}$ and elevated temperature; $\mathrm{eCO}_{2}+\mathrm{aT}$ : elevated $\mathrm{CO}_{2}$ and ambient temperature; and $\mathrm{eCO}_{2}+\mathrm{eT}$ : elevated $\mathrm{CO}_{2}$ and elevated temperature

$\left(\mathrm{eCO}_{2}+\mathrm{eT}\right)$ overlapped with the proteomes of oysters exposed to heat stress only $\left(\mathrm{aCO}_{2}+\mathrm{eT}\right)$ (Fig. $\left.2 \mathrm{~b}\right)$.

The combination of elevated $\mathrm{CO}_{2}$ and elevated temperature changed the expression patterns of 12 proteins and 13 genes (Fig. 1). The majority of differentially regulated proteins $(58 \%)$ and genes $(77 \%)$ were found at lower concentrations in $\mathrm{eCO}_{2}+\mathrm{eT}$ relative to ambient conditions $\left(\mathrm{aCO}_{2}+\mathrm{aT}\right)$. Proteins found in lower abundance in $\mathrm{eCO}_{2}+\mathrm{eT}$ oysters included actin (0.41-fold), Rho-GDI (0.67-fold) and protein spot 7516 (0.47-fold) (Fig. 2c). Genes down-regulated by elevated $\mathrm{CO}_{2}$ and elevated temperature included VWF (0.26-fold), perlucin (0.60-fold), multidrug resistance protein 1 (0.63-fold) and IgGFc-binding protein ( 0.63 -fold) (Fig. $3 \mathrm{~b})$. In contrast, charged multivesicular body protein $4 \mathrm{c}$ (2.02-fold), stress-induced protein 1 (1.88-fold) and protein spot 2312 (2.85-fold) were found at higher concentrations in $\mathrm{eCO}_{2}+\mathrm{eT}$ oysters (Fig. 2c). At the transcriptional level, ecSOD (1.90-fold), CYP1A1 (3.28-fold) and kelch 3 (1.55-fold) showed higher expression levels in $\mathrm{eCO}_{2}+\mathrm{eT}$ oysters relative to controls (Fig. 3b).

Only 3 proteins and 5 genes were affected by all stress treatments (elevated $\mathrm{CO}_{2}$ alone, elevated temperature alone, and the combination of elevated $\mathrm{CO}_{2}$ and elevated temperature) (Fig. 1). Rho-GDI, actin and an unidentified protein (spot no. 2311) were found in lower concentrations in oysters exposed to all three treatments $(0.22$ to 0.67 -fold) relative to oysters held under ambient conditions (Fig. 2c). At the transcriptional level, MEG10, Hsp70a, SMC3 and VWF were down-regulated by all of the treatments $(0.01$ to 0.65 -fold), while CYP1A1 transcripts were more abundant under $\mathrm{CO}_{2}$ and/or thermal stresses (3.28 to 6.88-fold) (Fig. 3b).

\section{Discussion}

B2 oysters represent a valuable genetic resource because of their capacity to withstand the impacts of $\mathrm{CO}_{2}$ stress at the physiological level $[30,33]$. They also appear to be capable of rapid acclimation or adaptation, responding faster than wild type oysters in the face of ocean acidification (OA) [35]. These features make this population a potential tool for climate-proofing Sydney rock oyster aquaculture and restoring natural oyster beds. The current study characterised the molecular profile of B2 oysters responding to realistic near-future scenarios that combine $\mathrm{OA}$ with ocean warming. By assessing the intracellular effects of elevated $\mathrm{CO}_{2}$ and increasing temperature, we found substantial changes in protein concentrations and gene expression in oyster gills following exposure to one or both stressors. Although the combination of these two stressors also altered the regulatory patterns of proteins and genes, the concurrent effects of elevated $\mathrm{CO}_{2}$ and temperature were not shown to be synergistic or additive.

\section{Overlapping responses to $\mathrm{OA}$, increasing temperature and the combined stressors}

A suite of proteins and genes showed substantial changes in expression in response to all stress treatments - elevated $\mathrm{CO}_{2}$ alone, elevated temperature alone, and combination of 
elevated $\mathrm{CO}_{2}$ and elevated temperature. This overlap in stress responses among treatments suggests that a similar set of molecular processes is recruited in the face of OA and warming in B2 oysters. The intracellular processes simultaneously affected by $\mathrm{OA}$ and/or increasing temperature were the control of redox balance, maintenance of cellular homeostasis, stress responses and the cytoskeleton. Differentially regulated molecules included Rho GDP dissociation inhibitor 1 (Rho-GDI), actin, Hsp70a, von Willebrand factor (VWF) D and EGF domain-containing protein, multiple epidermal growth factor-like domains proteins 10 (MEG10), structural maintenance of chromosomes 3 (SMC3) and a cytochrome P450 encoded by CYP1A1.

Rho-GDI and actin are of particular interest in the context of climate change resilience. Both proteins were found in lower concentrations in stress-exposed oysters relative to control conditions. Rho-GDI is an inhibitor of the small GTPase Rho, and is involved in oxidative stress and cytoskeleton organisation. Following interaction of Rho-GDI with membrane proteins, this complex activates $\mathrm{NADPH}$ oxidase, which in turn initiates the production of reactive oxygen species (ROS) [44]. Lower abundance of Rho-GDI has been observed in the mussel Mytilus galloprovincialis recovering from hyposaline stress [45]. The down-regulation of Rho-GDI found in our study may be associated with the control of oxidative damage that is typically induced by $\mathrm{OA}$ and rising temperature in oysters. The low abundance of Rho-GDI could prevent the formation of ROS in response to $\mathrm{CO}_{2}$ and/or thermal stresses in $\mathrm{B} 2$ oysters by reducing the activation of NADPH oxidase. Alternatively, the down-regulation of this protein could increase the activity of Rho GTPase, leading to cytoskeletal modifications. In this context, it is relevant that the major cytoskeletal protein, actin, was also found at lower concentrations in oysters exposed to any the three stress treatments. Actins are highly abundant structural proteins that play a fundamental role in the division, shape and mobility of eukaryotic cells. The changes observed in actin abundance could be related to cytoskeletal remodelling due to intracellular stress $[23,46]$.

At the transcriptional level, a gene encoding the stress response protein $\mathrm{Hsp} 70$ was also down-regulated in oysters exposed to any of the three stress treatments (OA, increased temperature and the combination of these stresses). Heat shock proteins, including Hsp70, are among the most abundant intracellular proteins protecting cells from stress-induced damage. Hsp70s act as molecular chaperones, promoting protein folding, membrane translocation, degradation of misfolded proteins and maintenance of cellular homeostasis [47]. Downregulation of Hsp70s following exposure to elevated $\mathrm{CO}_{2}$ has been previously shown in the oysters $C$. virginica and S. glomerata (B2 line) (pH 7.59 to 7.88; onemonth exposure; hemocytes and gills) $[19,22]$. In the pearl oyster, Pinctada fucata, Hsp70 mRNA levels increased immediately after exposure to elevated $\mathrm{CO}_{2}$ alone ( $\left.\mathrm{pH} 7.70,1425 \mu \mathrm{atm} p \mathrm{CO}_{2}\right)$, elevated temperature $\left(+3{ }^{\circ} \mathrm{C}\right.$ relative to control) alone and a combination of these stressors. However, Hsp70 expression in the mantle of $P$. fucata decreased after 4 days of stress exposure (relative to non-exposed oysters) [48]. In line with these studies, our findings suggest that longer exposures to stressful seawater conditions cause a decrease in the concentration of Hsp70. Such reductions in the expression of Hsp70, as well as of Rho-GDI and actin, may indicate that B2 oysters are prone to protein denaturation and cytoskeleton remodelling caused by $\mathrm{CO}_{2}$ and thermal stresses.

Exposure to $\mathrm{OA}$, increased temperature and the combination of both stresses also altered expression of genes involved in the maintenance of cellular homeostasis and the cell cycle. Genes encoding proteins that contain von Willebrand factor D (VWF) and EGF-like domains were substantially down-regulated in exposed B2 oysters. Von Willebrand factor D (VWF) and EGF domain-containing proteins are involved in the maintenance of cellular homeostasis, as well as in proteinprotein interactions and the assembly of protein subunits [49]. MEGF10, another gene down-regulated by all three stress treatments, encodes a membrane protein involved in phagocytosis of apoptotic cells, cell adhesion and motility. The expression of MEGF10 was down-regulated by hypoxia and hypo-osmotic stress in the Pacific oyster C. gigas (pool of tissues) [50]. A gene encoding SMC3 was also down-regulated by $\mathrm{CO}_{2}$ and/ or thermal stresses in the current study. SMC3 is a central component responsible for maintaining chromosome cohesion during cell division. In addition to its involvement in DNA replication and the cell cycle, SMC3 is associated with DNA repair [51]. To our knowledge, this is the first report showing differential regulation of SMC3 in response to stress in oysters. Due to this lack of information about the role that SMC3 plays in oysters, it is difficult to explain the implication of its low expression in stressed oysters. In contrast, CYP1A1 was the only molecule that showed increased expression in response to all three stress treatments. CYP1A1 is a member of the cytochrome P450 superfamily and encodes a protein that is involved in a variety of detoxification and endogenous processes, being the major form induced by xenobiotics, including dioxins, polycyclic aromatic hydrocarbons (PAHs) and polychlorinated biphenyls (PCBs) $[52,53]$. Induction of CYP1A1 transcription has been frequently reported after exposure to environmental stress, particularly chemical contaminants [53, 54]. The downregulation of genes involved in the cell cycle and maintenance of cellular homeostasis, along with the increased 
expression of CYP1A1, indicate that changes in seawater chemical and/or physical characteristics could have substantial effects on oyster growth and development, and their ability to respond to stress.

\section{Molecular responses induced by $\mathrm{OA}$}

Despite the similarities in responses to all three stress treatments (OA alone, increased temperature alone and the combination of these two stressors), each of the treatments produced additional unique impacts on different proteins and genes. $\mathrm{CO}_{2}$ stress by itself induced the greatest changes at the protein level among all of the treatments, both in terms of number of proteins affected and magnitude of those changes. Previous studies have shown that molluscs are particularly susceptible to OA [4-6, 15]. Changes in seawater chemistry have negative effects on growth, development, survival, calcification and acid-base regulation in different species of molluscs $[4,5,7]$. These changes are likely to be a reflection of complex rearrangements at the molecular level that ultimately result in physiological impacts [55]. Increasing temperature, in contrast, has not been shown to produce such strong impacts on the performance of molluscs [7]. Among the genes/proteins affected by $\mathrm{CO}_{2}$ stress alone in the current study, a number are associated with responses to stress, redox balance and cytoskeleton organisation. In the context of the molecules involved in redox balance, cytochrome b5 and ferritin were found at lower concentrations following exposure to elevated $\mathrm{CO}_{2}$. Both proteins participate in reduction-oxidation reactions and iron homeostasis. Given that these processes are linked to energy metabolism (through expression of Krebs cycle enzymes, for example), lower concentrations of cytochrome b5 and ferritin may be associated with shifts in energy requirements induced by $\mathrm{CO}_{2}$ stress [56].

Other stress-related genes affected by elevated $\mathrm{CO}_{2}$ alone included extracellular superoxide dismutase (ecSOD) and septin 2 (both up-regulated). EcSOD participates in ROS scavenging while septin is required for normal organization of the actin cytoskeleton $[16,57]$. Increased concentrations of ecSOD and septin 2 may be related to the capacity of $\mathrm{B} 2$ oysters to cope with oxidative damage typically induced by OA. They could mitigate damage to the actin cytoskeleton and other fundamental cellular components, minimising cell death through apoptosis. Overall, these findings suggest that B2 oysters may be able to withstand and limit the adverse impacts of $\mathrm{CO}_{2}$ stress on their physiological responses (i.e. growth, survival and metabolism) by hindering disturbance of the cellular redox balance and controlling cellular homeostasis.

\section{Molecular responses to increasing temperature}

Thermal stress alone also induced unique, substantial changes in the regulation of proteins and genes in B2 oysters. While elevated $\mathrm{CO}_{2}$ was the stress that altered the largest number of proteins, elevated temperature was responsible for the greatest changes at the transcriptional level. Thermal stress reduced the abundance of enolase and uracil-DNA glycosylase transcripts, but increased the levels of protein disulphide isomerase and stress-induced protein 1. Enolase participates in carbohydrate metabolism, specifically glycolysis, and may also be involved in stress responses [58]. Uracil-DNA glycosylase (UDG) is a major component of the cellular machinery responsible for DNA repair and prevention of DNA damage $[59,60]$. Very little information is available on the biological role and transcriptional regulation of enolase and UDG in molluscs responding to stress. However, our data might suggest that thermal stress reduces the ability of cells to control oxidative damage and resulting mutation, with consequences for the prevention of heat-induced cell death.

Protein disulphide isomerase (PDI) and stressinduced protein 1 were among the molecules whose expression was increased by thermal stress. PDI is a molecular chaperone found in the endoplasmic reticulum. It is involved in protein folding, assembly and post-translation modifications, including those induced by ROS [61]. Higher levels of PDI have also been observed in thermally-stressed sea cucumbers [62] and in larvae from Pacific oysters (C. gigas) exposed to the combination of elevated temperature $\left(+2{ }^{\circ} \mathrm{C}\right.$ relative to control) and elevated $\mathrm{CO}_{2}(\mathrm{pH} 7.9$, $656 \mu \mathrm{atm} p \mathrm{CO}_{2}$ ) [63]. In line with our results, stressinduced protein 1 , another molecular chaperone, was also found to be up-regulated in the gills of $C$. gigas following acute heat stress $\left(+20{ }^{\circ} \mathrm{C}\right.$ for $\left.1 \mathrm{~h}\right)$ [27]. It has been extensively reported that elevated temperature triggers oxidative stress in different species of marine invertebrates $[23,24,26]$. This response is often elicited by an imbalance between the production and neutralisation of ROS due to heat-induced metabolic shift and increased oxygen requirements. Our findings suggest that the increased expression of molecular chaperones may preserve correct conformation and stability of a number of proteins, in an attempt to prevent damage from thermally-driven stress.

Molecular responses to the combination of $\mathrm{OA}$ and warming The combination of $\mathrm{OA}$ and warming induced specific changes that were not evident when oysters were exposed to elevated $\mathrm{CO}_{2}$ or temperature alone. The combined stressors caused down-regulation of perlucin and multidrug resistance protein 1 . Perlucin is a C-type 
lectin involved in nucleation of calcium carbonate ions during shell formation [64-66]. Although the expression of perlucin may be expected to be altered by $\mathrm{CO}_{2}$-driven OA, no changes in its mRNA levels were observed in the mantle of the mussel Mytilus edulis after exposure to elevated $\mathrm{CO}_{2}\left(\mathrm{pH} 7.8,766 \mu\right.$ atm $p \mathrm{CO}_{2}, 60$-day exposure) $[67,68]$. In contrast, higher levels of perlucin was observed in gills of $\mathrm{B} 2$ oysters following transgenerational exposure to $\mathrm{CO}_{2}$ stress alone $(\mathrm{pH} 7.77,1067 \mu \mathrm{atm}$ $p \mathrm{CO}_{2}$, 4-week exposure) (Goncalves et al., in preparation). Therefore, it appears that B2 oysters could be able to maintain carbonate homeostasis and shell deposition under $\mathrm{CO}_{2}$ stress alone, but their calcification process may be hampered when increased temperature is combined to $\mathrm{CO}_{2}$ stress. Multidrug resistance proteins play a role in detoxifying various toxic agents in marine organisms due to their ability to transport xenobiotic conjugates and metabolites [69]. Our findings indicate that multidrug resistance protein 1 may also participate in oyster responses to OA and warming.

Combined, the substantial changes in protein and gene expression observed in this study suggest that the inducible responses of oysters to near-future changes in seawater temperature and $\mathrm{pH}$ may depend upon energy reallocation. Such reallocation could regulate fundamental cellular processes, including control of oxidative damage, maintenance of cellular homeostasis and immune responses. Although testing the physiological outcomes of this stress-induced energy reallocation was beyond the scope of our study, it is likely that these intracellular changes have an impact on oyster growth and survival (as previously shown by $[10,30,70])$ as well as on the immune functions and response to infectious diseases. Intracellular changes induced by thermal stress in Pacific oysters (C. gigas) have been related to potential susceptibility to infectious diseases [71-73].

\section{Concurrent effects of $\mathrm{OA}$ and warming are not synergistic or additive}

Numerous studies suggest that exposure to elevated $\mathrm{CO}_{2}$ enhances the responsiveness of marine organisms to thermal stress and vice versa [74-76]. However, our data did not reveal such a synergistic or additive interaction at the molecular level. In the context of the current study, synergistic or additive effects would have been reflected in more substantial responses, in terms of the number or fold changes of differentially expressed genes and proteins, when the combined effects of elevated $\mathrm{CO}_{2}$ and temperature were compared to those stressors in isolation. By this definition, our data did not identify synergistic or additive effects of elevated $\mathrm{CO}_{2}$ and temperature. This lack of additive or synergistic interactions may be due to limitations in our experimental design or to potentially antagonistic effects of $\mathrm{OA}$ and increasing temperature in $\mathrm{B} 2$ oysters. Variability in $\mathrm{pH}$ and temperatures (but not in $p \mathrm{CO}_{2}$ concentrations) were observed among the different treatments as a consequence of our experimental design. Tanks for elevated $\mathrm{CO}_{2}$ and elevated temperature treatments were supplied by independent seawater reservoirs. This resulted in unintended, albeit minor differences in seawater chemistry and temperature among the treatments. These differences may have prevented us from identifying synergistic or additive effects by $\mathrm{CO}_{2}$ and thermal stresses.

The lack of a synergistic or additive response might also have been due to the differential performance of B2 oysters under climate change-associated conditions. If that is the case, the combination of $\mathrm{OA}$ and increased temperature would induce antagonistic effects in these oysters. Previous studies have reported that thermal stress ameliorates some impacts of elevated $\mathrm{CO}_{2}$. Increasing temperature $\left(+2{ }^{\circ} \mathrm{C}\right.$ to $3.2{ }^{\circ} \mathrm{C}$ relative to control conditions) minimised the negative effects of elevated $\mathrm{CO}_{2}$ (resulting in $\mathrm{pH} 7.79$ to 7.90 ) on growth and calcification rate of C. gigas larvae [63], and on calcification of coral reefs [77] and the sea star Pisaster ochraceus [78]. Similarly, a recent meta-analysis assessing the physiological responses of marine organisms to OA and warming revealed restorative effects of the combined stressors on the growth of echinoderms and calcifying phytoplankton, and on photosynthesis of calcifying and noncalcifying marine autotrophs. It has also been shown that OA alone negatively affects both calcification and photosynthesis in corals, while these processes were not disturbed by the combination of $\mathrm{OA}$ and increased temperature [7]. In line with these findings, our data suggest that the addition of warming may alleviate the effects of acidification on the molecular responses of oysters. Alternatively, our results might imply that the combination of elevated $\mathrm{CO}_{2}$ and temperature cumulatively overwhelms the stress response system of B2 oysters, so that their intracellular processes more closely resemble those of oysters held under ambient conditions compared to those exposed to elevated $\mathrm{CO}_{2}$ or temperature in isolation.

\section{Conclusions}

The current study has investigated the impacts of ocean acidification and warming on gill proteomes and transcriptional responses of B2 oysters. Our findings show that low seawater $\mathrm{pH}$ and elevated temperature affect a variety of biological processes at the protein and transcriptional levels. These effects are not additive or synergistic and may be antagonistic, even though many of the same intracellular processes are affected by elevated $\mathrm{CO}_{2}$ and elevated temperature when the stressors are applied separately. The differential responses observed in oysters 
exposed to a combination of stressors indicate that the inherent capacity of $\mathrm{B} 2$ oysters to cope with elevated $\mathrm{CO}_{2}$ that was described at the physiological level may not be substantially relevant once thermal stress is added in marine environments. Further studies are required to clarify the complex biological outcomes of the concurrent exposure to ocean acidification and warming, as well as to elucidate the potential of $\mathrm{B} 2$ oysters to further acclimate or adapt to such stressful conditions.

\section{Additional files}

Additional file 1: Table S1. Primers used for qPCR analysis. (XLSX $15 \mathrm{~kb}$ ) Additional file 2: Table S2. List of proteins identified by mass spectrometry that were differentially regulated by $\mathrm{CO}_{2}$ and/or thermal stress. Fold changes $(\mathrm{FC})$ were calculated from the mean normalised intensities of protein spots relative to the control, ambient condition $\left(\mathrm{aCO}_{2}+\mathrm{aT}\right)$. $\mathrm{FC}$ values $>1$ reflect up-regulation in the elevated treatment relative to ambient controls. FC values $<1$ reflect down-regulation in the elevated treatment. The table also shows arbitrarily assigned protein spot numbers, putative identifications (description) and their respective accession numbers based on homology to a Mollusca nr database, spectral counts, $\log (\mathrm{e})$ values, isoelectric points (pl) and molecular weights (MW) $\mathrm{aCO}_{2}+\mathrm{eT}$ : ambient $\mathrm{CO}_{2}$ and elevated temperature; $\mathrm{eCO}_{2}+$ aT: elevated $\mathrm{CO}_{2}$ and ambient temperature; and $\mathrm{eCO}_{2}+$ eT: elevated $\mathrm{CO}_{2}$ and elevated temperature. (XLSX $18 \mathrm{~kb})$

\section{Acknowledgments}

The authors are grateful to Dr. Wayne A. O'Connor and staff from the Port Stephens Fisheries Institute (PSFI), New South Wales Department of Primary Industries (NSW DPI), for providing the B2 line oysters and for their support, to Prof. Ian Paulsen and Dr. Natalie Curach from Macquarie University for providing access to the qPCR facilities, to Dr. Emma Wilkie for her help with sample processing and 2D gel electrophoresis, to Vineet Vaibhav for his help with mass spectrometry and to Dr. Diego R. Barneche for his assistance with the statistical analysis.

\section{Funding}

P. Goncalves was partially supported by a PhD scholarship provided by CNPq-Brazil and by an International Macquarie University Research Excellence (iMQRES) postgraduate scholarship from Macquarie University. This research was supported by Macquarie University PhD funding and an Australian Research Council (ARC) Discovery grant to D. Raftos and others (DP120101946).

\section{Availability of data and materials}

The datasets supporting the conclusions of this article are included within the article and its supporting information files.

\section{Authors' contributions}

PG, ELT and DAR conceived and designed the experiments. PG and ELT performed the experimental exposure and sampling. PG processed the samples, performed the molecular analyses and analysed the data. PG and DAR wrote the manuscript. All authors read and approved the final manuscript.

\section{Competing interests}

The authors declare that they have no competing interests.

\section{Publisher's Note}

Springer Nature remains neutral with regard to jurisdictional claims in published maps and institutional affiliations.

\section{Author details}

'Department of Biological Sciences, Macquarie University, Sydney, NSW 2109, Australia. ${ }^{2}$ Sydney Institute of Marine Science, Chowder Bay, Sydney, NSW 2088, Australia. ${ }^{3}$ Present Address: School of Life and Environmental Science, The University of Sydney, Sydney, NSW 2006, Australia.
Received: 18 October 2016 Accepted: 25 May 2017

Published online: 02 June 2017

\section{References}

1. IPCC. Climate change 2013: the physical science basis. In: Stocker TF, Qin D, Platter G-K, Tignor M, Allen SK, Boschung J, Nauels A, Xia Y, Bex V, Midgley PM, editors. Contribution of working group I to the fifth assessment report of the intergovernmental panel on climate change. Cambridge, New York: Cambridge University Press; 2013. p. 1535.

2. Pörtner $\mathrm{HO}$, Langenbuch $\mathrm{M}$, Reipschlager A. Biological impact of elevated ocean $\mathrm{CO}_{2}$ concentrations: lessons from animal physiology and earth history. J Oceanogr. 2004;60(4):705-18.

3. Fabry VJ. Ocean science. Marine calcifiers in a high- $\mathrm{CO}_{2}$ ocean. Science. 2008;320(5879):1020-2

4. Parker LM, Ross PM, Connor W, Pörtner H, Scanes E, Wright J. Predicting the response of molluscs to the impact of ocean acidification. Biology. 2013; 2(2):651-92.

5. Gazeau F, Parker LM, Comeau S, Gattuso JP, O'Connor WA, Martin S, et al. Impacts of ocean acidification on marine shelled molluscs. Mar Biol. 2013; 160(8):2207-45.

6. Miller AW, Reynolds AC, Sobrino C, Riedel GF. Shellfish face uncertain future in high $\mathrm{CO}_{2}$ world: influence of acidification on oyster larvae calcification and growth in estuaries. PLoS One. 2009;4(5):e5661.

7. Harvey BP, Gwynn-Jones D, Moore PJ. Meta-analysis reveals complex marine biological responses to the interactive effects of ocean acidification and warming. Ecol Evol. 2013;3(4):1016-30.

8. Kroeker KJ, Kordas RL, Crim R, Hendriks IE, Ramajo L, Singh GS, et al. Impacts of ocean acidification on marine organisms: quantifying sensitivities and interaction with warming. Glob Chang Biol. 2013;19(6):1884-96.

9. Amaral V, Cabral HN, Bishop MJ. Effects of estuarine acidification on predator-prey interactions. Mar Ecol Prog ser. 2012;445:117-27.

10. Dickinson GH, Ivanina AV, Matoo OB, Pörtner HO, Lannig G, Bock C, et al. Interactive effects of salinity and elevated $\mathrm{CO} 2$ levels on juvenile eastern oysters, Crassostrea virginica. J exp Biol. 2012;215(Pt 1):29-43.

11. Wang Q, Cao R, Ning X, You L, Mu C, Wang C, et al. Effects of ocean acidification on immune responses of the Pacific oyster Crassostrea gigas. Fish Shellfish Immunol. 2016;49:24-33.

12. Timmins-Schiffman E, Coffey WD, Hua W, Nunn BL, Dickinson GH, Roberts SB. Shotgun proteomics reveals physiological response to ocean acidification in Crassostrea gigas. BMC Genomics. 2014;15(1):951.

13. Wei L, Wang Q, Ning X, Mu C, Wang C, Cao R, et al. Combined metabolome and proteome analysis of the mantle tissue from Pacific oyster Crassostrea gigas exposed to elevated $\mathrm{DCO}_{2}$. Comp Biochem Physiol Part D Genomics Proteomics. 2015;13:16-23.

14. Dineshram R, Wong KKW, Xiao S, Yu ZN, Qian PY, Thiyagarajan V. Analysis of Pacific oyster larval proteome and its response to high- $\mathrm{CO}_{2}$. Mar Pollut Bull. 2012;64(10):2160-7.

15. Dineshram R, Chandramouli K, Ko GWK, Zhang H, Qian P-Y, Ravasi T, et al. Quantitative analysis of oyster larval proteome provides new insights into the effects of multiple climate change stressors. Glob Chang Biol. 2016;22(6): 2054-68.

16. Tomanek L, Zuzow MJ, Ivanina AV, Beniash E, Sokolova IM. Proteomic response to elevated $\mathrm{PCO}_{2}$ level in eastern oysters, Crassostrea virginica: evidence for oxidative stress. J exp Biol. 2011;214(11):1836-44.

17. Dineshram R, Thiyagarajan V, Lane A, Yu ZN, Shu X, Leung PTY. Elevated $\mathrm{CO}_{2}$ alters larval proteome and its phosphorylation status in the commercial oyster, Crassostrea hongkongensis. Mar Biol. 2013;160(8): 2189-205.

18. Dineshram R, Quan Q, Sharma R, Chandramouli K, Yalamanchili HK, Chu I, et al. Comparative and quantitative proteomics reveal the adaptive strategies of oyster larvae to ocean acidification. Proteomics. 2015;15(23-24):4120-34.

19. Thompson EL, O'Connor W, Parker L, Ross P, Raftos DA. Differential proteomic responses of selectively bred and wild Sydney rock oyster populations exposed to elevated $\mathrm{CO}_{2}$. Mol Ecol. 2015;24(6):1248-62.

20. Thompson EL, Parker L, Amaral V, Bishop MJ, O'Connor WA, Raftos DA. Wild populations of Sydney rock oysters differ in their proteomic responses to elevated carbon dioxide. Mar Freshw Res. 2016;67:1964-72.

21. Beniash E, Ivanina A, Lieb NS, Kurochkin I, Sokolova IM. Elevated level of carbon dioxide affects metabolism and shell formation in oysters Crassostrea virginica. Mar Ecol Prog ser. 2010;419:95-108. 
22. Ivanina AV, Hawkins C, Sokolova IM. Immunomodulation by the interactive effects of cadmium and hypercapnia in marine bivalves Crassostrea virginica and Mercenaria mercenaria. Fish Shellfish Immunol. 2014;37(2):299-312.

23. Tomanek L. Proteomics to study adaptations in marine organisms to environmental stress. J Proteome. 2014;105(0):92-106.

24. Zhang G, Fang X, Guo X, Li L, Luo R, Xu F, et al. The oyster genome reveals stress adaptation and complexity of shell formation. Nature. 2012;490(7418):49-54.

25. Farcy E, Voiseux C, Lebel JM, Fievet B. Transcriptional expression levels of cell stress marker genes in the Pacific oyster Crassostrea gigas exposed to acute thermal stress. Cell Stress Chaperones. 2009;14(4):371-80.

26. Meistertzheim AL, Tanguy A, Moraga D, Thebault MT. Identification of differentially expressed genes of the Pacific oyster Crassostrea gigas exposed to prolonged thermal stress. FEBS J. 2007;274(24):6392-402.

27. Zhang Y, Sun J, Mu H, Li J, Zhang Y, Xu F, et al. Proteomic basis of stress responses in the gills of the pacific oyster Crassostrea gigas. J Proteome res. 2015;14(1):304-17.

28. Clark MS, Thorne MA, Amaral A, Vieira F, Batista FM, Reis J, et al. Identification of molecular and physiological responses to chronic environmental challenge in an invasive species: the Pacific oyster, Crassostrea gigas. Ecol Evol. 2013;3(10):3283-97.

29. Chapman RW, Mancia A, Beal M, Veloso A, Rathburn C, Blair A, et al. The transcriptomic responses of the eastern oyster, Crassostrea virginica, to environmental conditions. Mol Ecol. 2011;20(7):1431-49.

30. Parker LM, Ross PM, O'Connor WA, Borysko L, Raftos DA, Pörtner H. Adult exposure influences offspring response to ocean acidification in oysters. Glob Chang Biol. 2012;18(1):82-92.

31. Thomsen J, Melzner F. Moderate seawater acidification does not elicit longterm metabolic depression in the blue mussel Mytilus edulis. Mar Biol. 2010; 157(12):2667-76.

32. Lang RP, Bayne CJ, Camara MD, Cunningham C, Jenny MJ, Langdon CJ. Transcriptome profiling of selectively bred Pacific oyster Crassostrea gigas families that differ in tolerance of heat shock. Mar Biotechnol. 2009;11(5):650-68.

33. Parker LM, Ross PM, O'Connor WA. Populations of the Sydney rock oyster, Saccostrea glomerata, vary in response to ocean acidification. Mar Biol. 2011; 158(3):689-97.

34. Dove MC, Nell JA, O'Connor WA. Evaluation of the progeny of the fourthgeneration Sydney rock oyster Saccostrea glomerata (Gould, 1850) breeding lines for resistance to QX disease (Marteilia sydneyi) and winter mortality (Bonamia roughleyi). Aquac res. 2013;44(11):1791-800.

35. Goncalves P, Anderson K, Thompson EL, Melwani A, Parker LM, Ross PM, et al. Rapid transcriptional acclimation following transgenerational exposure of oysters to ocean acidification. Mol Ecol. 2016;25(19):4836-49.

36. Spiers ZB, Gabor M, Fell SA, Carnegie RB, Dove M, OC W, et al. Longitudinal study of winter mortality disease in Sydney rock oysters Saccostrea glomerata. Dis Aquat org. 2014;110(1-2):151-64.

37. Nell J: Manual for mass selection of Sydney rock oysters for fast growth and disease resistance. In: NSW Department of Primary Industries - Fisheries Research Report Series. Australia: NSW Department of Primary Industries; 2006.

38. Xie FL, Sun GL, Stiller JW, Zhang BH. Genome-wide functional analysis of the cotton transcriptome by creating an integrated EST database. PLoS One. 2011;6: e26980.

39. Livak KJ, Schmittgen TD. Analysis of relative gene expression data using real-time quantitative $P C R$ and the 2(-Delta Delta $C(T))$ method. Methods. 2001;25(4):402-8.

40. Bradford MM. A rapid and sensitive method for the quantitation of microgram quantities of protein utilizing the principle of protein-dye binding. Anal Biochem. 1976;72:248-54.

41. Candiano G, Bruschi M, Musante L, Santucci L, Ghiggeri GM, Carnemolla B, et al. Blue silver: a very sensitive colloidal Coomassie G-250 staining for proteome analysis. Electrophoresis. 2004;25(9):1327-33.

42. Craig R, Beavis RC. A method for reducing the time required to match protein sequences with tandem mass spectra. Rapid Commun Mass Spectrom. 2003;17(20):2310-6.

43. Craig R, Beavis RC. TANDEM: matching proteins with tandem mass spectra. Bioinformatics. 2004;20(9):1466-7.

44. Di-Poi N, Faure J, Grizot S, Molnar G, Pick E, Dagher MC. Mechanism of NADPH oxidase activation by the Rac/rho-GDI complex. Biochemistry. 2001; 40(34):10014-22.

45. Tomanek L, Zuzow MJ, Hitt L, Serafini L, Valenzuela JJ. Proteomics of hyposaline stress in blue mussel congeners (genus Mytilus): implications for biogeographic range limits in response to climate change. J exp Biol. 2012; 215(Pt 22):3905-16.

46. McDonagh B, Sheehan D. Effects of oxidative stress on protein thiols and disulphides in Mytilus edulis revealed by proteomics: Actin and protein disulphide isomerase are redox targets. Mar Environ res. 2008;66(1):193-5.

47. Liu D, Chen Z. The expression and induction of heat shock proteins in molluscs. Protein Pept Lett. 2013;20(5):602-6.

48. Liu W, Huang X, Lin J, He M. Seawater acidification and elevated temperature affect gene expression patterns of the pearl oyster Pinctada fucata. PLoS One. 2012;7(3):e33679.

49. Whittaker CA, Hynes RO. Distribution and evolution of von Willebrand/ integrin a domains: widely dispersed domains with roles in cell adhesion and elsewhere. Mol Biol Cell. 2002;13(10):3369-87.

50. Sussarellu R, Fabioux C, Le Moullac G, Fleury E, Moraga D. Transcriptomic response of the Pacific oyster Crassostrea gigas to hypoxia. Mar Genomics. 2010;3(3-4):133-43.

51. Brinch $M$, Hatt L, Singh R, Moller K, Sommer S, Uldbjerg N, et al. Identification of circulating fetal cell markers by microarray analysis. Prenat Diagn. 2012;32(8):742-51.

52. Snyder MJ. Cytochrome P450 enzymes in aquatic invertebrates: recent advances and future directions. Aquat Toxicol. 2000:48(4):529-47.

53. Luchmann KH, Clark MS, Bainy AC, Gilbert JA, Craft JA, Chipman JK, et al. Key metabolic pathways involved in xenobiotic biotransformation and stress responses revealed by transcriptomics of the mangrove oyster Crassostrea brasiliana. Aquat Toxicol. 2015;166:10-20.

54. Boutet I, Tanguy A, Moraga D. Response of the Pacific oyster Crassostrea gigas to hydrocarbon contamination under experimental conditions. Gene. 2004;329:147-57.

55. Somero GN. The physiology of climate change: how potentials for acclimatization and genetic adaptation will determine 'winners' and 'losers'. J exp Biol. 2010;213(6):912-20.

56. Tomanek L. Environmental proteomics: changes in the proteome of marine organisms in response to environmental stress, pollutants, infection, symbiosis, and development. Annu rev mar Sci. 2011;3(1):373-99.

57. Kremer BE, Adang LA, Macara IG. Septins regulate actin organization and cell-cycle arrest through nuclear accumulation of NCK mediated by SOCS7. Cell. 2007;130(5):837-50.

58. Gerlt JA, Babbitt PC, Rayment I. Divergent evolution in the enolase superfamily: the interplay of mechanism and specificity. Arch Biochem Biophys. 2005:433(1):59-70.

59. Krokan HE, Nilsen H, Skorpen F, Otterlei M, Slupphaug G. Base excision repair of DNA in mammalian cells. FEBS Lett. 2000:476(1-2):73-7.

60. David SS, O'Shea VL, Kundu S. Base-excision repair of oxidative DNA damage. Nature. 2007;447(7147):941-50.

61. Tu BP, Weissman JS. Oxidative protein folding in eukaryotes: mechanisms and consequences. J Cell Biol. 2004;164(3):341-6.

62. Zhang P, Lu Y, Li C, Su X, Wang Z, Jin C, et al. Identification of differential expressed proteins and characterization their mRNA expression in thermally stressed Apostichopus japonicus. Comp Biochem Physiol Part D: Genomics Proteomics. 2013;8(3):194-200.

63. Harney E, Artigaud S, Le Souchu P, Miner P, Corporeau C, Essid H, et al. Non-additive effects of ocean acidification in combination with warming on the larval proteome of the Pacific oyster, Crassostrea gigas. J Proteome. 2016;135:151-61.

64. Mann K, Weiss IM, André S, Gabius H-J, Fritz M. The amino-acid sequence of the abalone (Haliotis laevigata) nacre protein perlucin. Eur J Biochem. 2000; 267(16):5257-64.

65. Weiss IM, Kaufmann S, Mann K, Fritz M. Purification and characterization of perlucin and perlustrin, two new proteins from the shell of the mollusc Haliotis laevigata. Biochem Biophys res Commun. 2000;267(1):17-21.

66. Blank S, Arnoldi M, Khoshnavaz S, Treccani L, Kuntz M, Mann K, et al. The nacre protein perlucin nucleates growth of calcium carbonate crystals. J Microsc. 2003;212(Pt 3):280-91.

67. Li S, Liu C, Huang J, Liu Y, Zheng G, Xie L, et al. Interactive effects of seawater acidification and elevated temperature on biomineralization and amino acid metabolism in the mussel Mytilus edulis. J exp Biol. 2015;218(22): 3623-31.

68. Hüning A, Melzner F, Thomsen J, Gutowska M, Krämer L, Frickenhaus S, et al. Impacts of seawater acidification on mantle gene expression patterns of the Baltic Sea blue mussel: implications for shell formation and energy metabolism. Mar Biol. 2013;160(8):1845-61. 
69. Kingtong S, Chitramvong Y, Janvilisri T. ATP-binding cassette multidrug transporters in Indian-rock oyster Saccostrea forskali and their role in the export of an environmental organic pollutant tributyltin. Aquat Toxicol. 2007;85(2):124-32.

70. Parker LM, O'Connor WA, Raftos DA, Pörtner HO, Ross PM. Persistence of positive carryover effects in the oyster, Saccostrea glomerata, following transgenerational exposure to ocean acidification. PLoS One. 2015;10(7): e0132276.

71. Green TJ, Montagnani C, Benkendorff K, Robinson N, Speck P. Ontogeny and water temperature influences the antiviral response of the Pacific oyster, Crassostrea gigas. Fish Shellfish Immunol. 2014;36(1):151-7.

72. Wendling CC, Fabritzek AG, Wegner KM. Population-specific genotype $x$ genotype $x$ environment interactions in bacterial disease of early life stages of Pacific oyster larvae. Evol Appl. 2017;10:338-47.

73. Pernet F, Lupo C, Bacher C, Whittington RJ. Infectious diseases in oyster aquaculture require a new integrated approach. Philos Trans R Soc B. 2016; 371(1689). doi:10.1098/rstb.2015.0213.

74. Feidantsis K, Pörtner HO, Antonopoulou E, Michaelidis B. Synergistic effects of acute warming and low $\mathrm{pH}$ on cellular stress responses of the gilthead seabream Sparus aurata. J Comp Physiol B. 2015;185(2):185-205.

75. Gunderson AR, Armstrong EJ, Stillman JH. Multiple stressors in a changing world: The need for an improved perspective on physiological responses to the dynamic marine environment. Ann Rev Mar Sci. 2016;8:357-78.

76. Albright $\mathrm{R}$, Mason B. Projected near-future levels of temperature and $p \mathrm{CO}_{2}$ reduce coral fertilization success. PLoS One. 2013;8(2):e56468.

77. McNeil BI, Matear RJ, Barnes DJ. Coral reef calcification and climate change: The effect of ocean warming. Geophys res Lett. 2004;31(22):L22309.

78. Gooding RA, Harley CD, Tang E. Elevated water temperature and carbon dioxide concentration increase the growth of a keystone echinoderm. Proc Natl Acad Sci. 2009;106(23):9316-21.

\section{Submit your next manuscript to BioMed Central and we will help you at every step:}

- We accept pre-submission inquiries

- Our selector tool helps you to find the most relevant journal

- We provide round the clock customer support

- Convenient online submission

- Thorough peer review

- Inclusion in PubMed and all major indexing services

- Maximum visibility for your research

Submit your manuscript at www.biomedcentral.com/submit 